\title{
The load factor in bolted timber joints under external tensile loads
}

\author{
Doppo Matsubara ${ }^{1 *}$ (D) Yoshiaki Wakashima ${ }^{2}$, Hidemaru Shimizu ${ }^{3}$ and Akihisa Kitamori ${ }^{4}$
}

\begin{abstract}
These experiments sought to empirically determine how the initial tightening force influences the ratio of the axial bolt force to the tensile load (load factor) and the load required to separate the joint interface (interface separation load) in tensile bolted joints of glued laminated timber. Load factor decreases with increasing initial tightening force; however, this tendency is reduced the greater the washer-member-end distance. In addition, tensile stiffness increases with decreasing load factor, and the interface separation load increases with increasing initial tightening force. However, in actual testing, the joint interface separated at a lower load that predicted mathematically based on the load factor and initial tightening force.
\end{abstract}

Keywords: Load factor, Bolted timber joints, Glued laminated timber, Tightening force

\section{Introduction}

Bolted joints are the most common type of joining method utilized in wooden structures [1]. Bolted joints are tightened with a nut during their installation, however, the force generated (initial tightening force) cannot hold up in the long term due to stress relaxation of the wood [2]. However, the frictional resistance between members produced by this force not only improves the joint's stiffness and strength, but also its long-term damping capacity [3-8]. The authors have long been interested in developing load-bearing walls, which leverage the friction created when wooden members are fastened together (or to steel plate) with bolts or lag screws. Our team has already reported on the structural performance of these joints [9-11], how to control the initial tightening force [12-15], and their long-term stress relaxation behavior [16-18]. In the last case, we have shown that these joints can withstand relatively high stress when the initial tightening force exceeds the compressive yield point of the wood, even when exposed to repeated wetdry cycles [18]; and that they can withstand at least $70 \%$

\footnotetext{
*Correspondence: matsubara.doppo@iri-tokyo.jp

${ }^{1}$ Tokyo Metropolitan Industrial Technology Research Institute, 2-4-10, Aomi, Koto-Ku, Tokyo 135-0064, Japan

Full list of author information is available at the end of the article
}

of any vertical compressive stress applied to the wood, even in a high-temperature, constant-humidity environment [17].

While our understanding of the mechanical properties and stress relaxation behavior of bolted joints under an initial tightening force (simply "fastened" below) continues to improve, nearly all studies on the subject have concerned their shear resistance. The resistance of bolted joints can be analyzed in two respects-in response to a tensile force, or a shear force-but there have been no basic research to date into the behavior of fastened bolted joints subjected to a load parallel to the bolt axis.

When a tensile load acts on fastened bolted joint, not all of it is counteracted by the axial bolt force: some is borne by a clamp force at the joint interface (resulting from the initial tightening force). The ratio of the increase in the bolt axial force to the load is known as the load factor, an important value in design specifications; however, nearly research on it has been in the context of bolted joints in mechanical structures (e.g., pressure vessels, plants, automobiles) [19-26]. When a tensile load acts on an unfastened bolted timber joint, the concept of load factor can be applied to deduce that, since $100 \%$ is borne by the bolt, the clamping force at the interface is reduced to zero, and the two members completely separate. Conversely, fastening the bolt with the initial tightening force
Springer Open (c) The Author(s) 2020. This article is licensed under a Creative Commons Attribution 4.0 International License, which permits use, sharing, adaptation, distribution and reproduction in any medium or format, as long as you give appropriate credit to the original author(s) and the source, provide a link to the Creative Commons licence, and indicate if changes were made. The images or other third party material in this article are included in the article's Creative Commons licence, unless indicated otherwise in a credit line to the material. If material is not included in the article's Creative Commons licence and your intended use is not permitted by statutory regulation or exceeds the permitted use, you will need to obtain permission directly from the copyright holder. To view a copy of this licence, visit http://creativeco mmons.org/licenses/by/4.0/. 
both decreases the axial load on the bolt itself and prevents the members from separating at the interface. This makes the load factor a crucial quantity for our understanding of the behavior of fastened bolted joints under tensile loads. However, there have been no studies that explore the effects of the initial tightening force on the load factor, or the force at which the members come apart (interface separation load), in bolted timber joints.

This study consisted of tensile testing of tensile bolt joints, a tension/moment-resistance type of joint [2732], fastened by an initial tightening force. The specific goals were to gain basic knowledge about how this force affects the load factor and interface separation load in bolted timber joints.

\section{Load factor}

Figure 1 shows a bolted joint. Two wooden members are clamped together with a bolt and nut by initial tightening force $F_{\mathrm{f}}$. When external load $W$ acts parallel to the bolt axis, the bolt axial force increases by $F_{\mathrm{t}}$, while the force at the interface decreases by $F_{\mathrm{c}}$. This can be expressed as:

$$
W=F_{\mathrm{t}}+F_{\mathrm{c}} .
$$

This equation can be applied until the joint interface is completely separated. Unfortunately, this equation has two unknowns, making it a statically indeterminate system.

The ratio of $F_{\mathrm{t}}$ (the increased axial force on the bolt) to $W$ is expressed by $\phi$, a quantity known as the load factor [19]:

$$
\phi=\frac{F_{\mathrm{t}}}{W}
$$

Substituting (2) into (1) yields

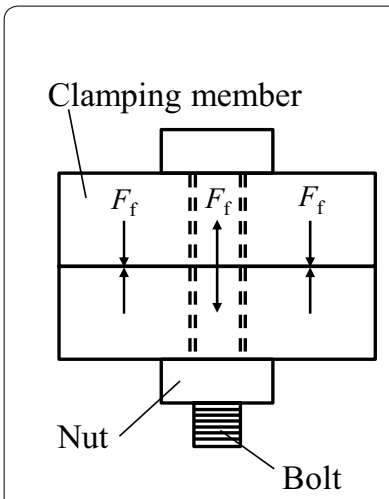

a Initial clamping state

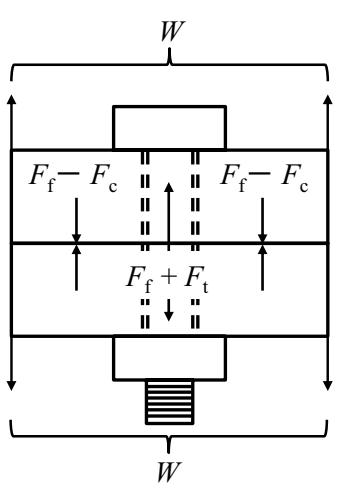

b When external tensile load is applied
Fig. 1 A bolted joint under an external tensile load

$$
F_{\mathrm{c}}=(1-\phi) W .
$$

If $\phi$ is known, $F_{\mathrm{t}}$ and $F_{\mathrm{c}}$ can be derived. These series of equations imply that lower values of $\phi$ result in greater $F_{\mathrm{c}}$ and less residual stress at the joint interface. In addition, higher values of $\phi$ result in greater $F_{\mathrm{t}}$, a greater proportion of $W$ acting on the bolt, and greater axial deformation. Figure 2 is a schematic diagram of how $\phi$ should be conceived based on the equations above. Axial bolt force $\left(F_{\mathrm{f}}+F_{\mathrm{t}}\right)$ is on the vertical axis, the external load $(W)$ is on the horizontal axis, and $\phi$ is the slope of the initial line. Once $W$ becomes large enough to completely separate the joint interface, the axial bolt force becomes equal to $W$. This interface separation load ( $\left.W_{\text {sep }}\right)$ can be expressed as

$$
W_{\text {sep }}=\frac{F_{\mathrm{f}}}{1-\phi} .
$$

This equation signifies that $W_{\text {sep }}$ can be increased by maximizing $F_{\mathrm{f}}$. While it likewise means that large values of $\phi$ would have the same effect, this would simultaneously increase the load on the bolt, as noted above. The salient points to remember when designing a bolted timber joint with minimal bolt deformation and interfacial separation are to configure $\phi$ as low as possible, and $F_{\mathrm{f}}$ as large as possible.

\section{Materials and methods}

Figure 3 shows a schematic of the experimental set-up. Wood specimens were heterogenous glued laminated timber ("glulam") of Japanese larch (Larix kaempferi, grade: E105-F300 (by Japanese agricultural standard), density [mean \pm S.D.]: $541 \pm 50.00 \mathrm{~kg} / \mathrm{m}^{3}$, moisture content: $9.4 \pm 1.05 \%)$. Bolts were M12 double-ended studs (pitch: $1.75 \mathrm{~mm}$, material: $\mathrm{Z}$ mark fastener by standard of Japan Housing and Wood Technology Center). Washer A

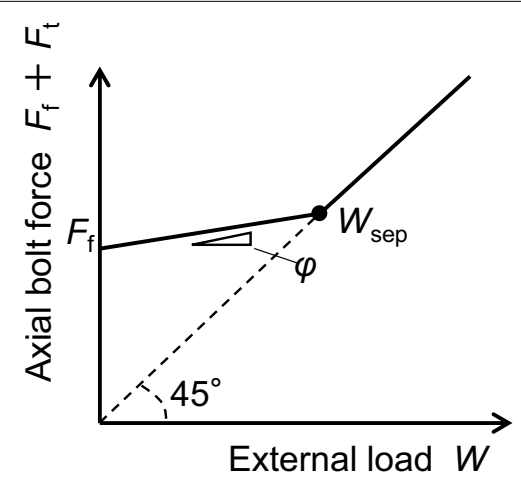

Fig. 2 Schematic diagram of the relationship between axial bolt force and external load 


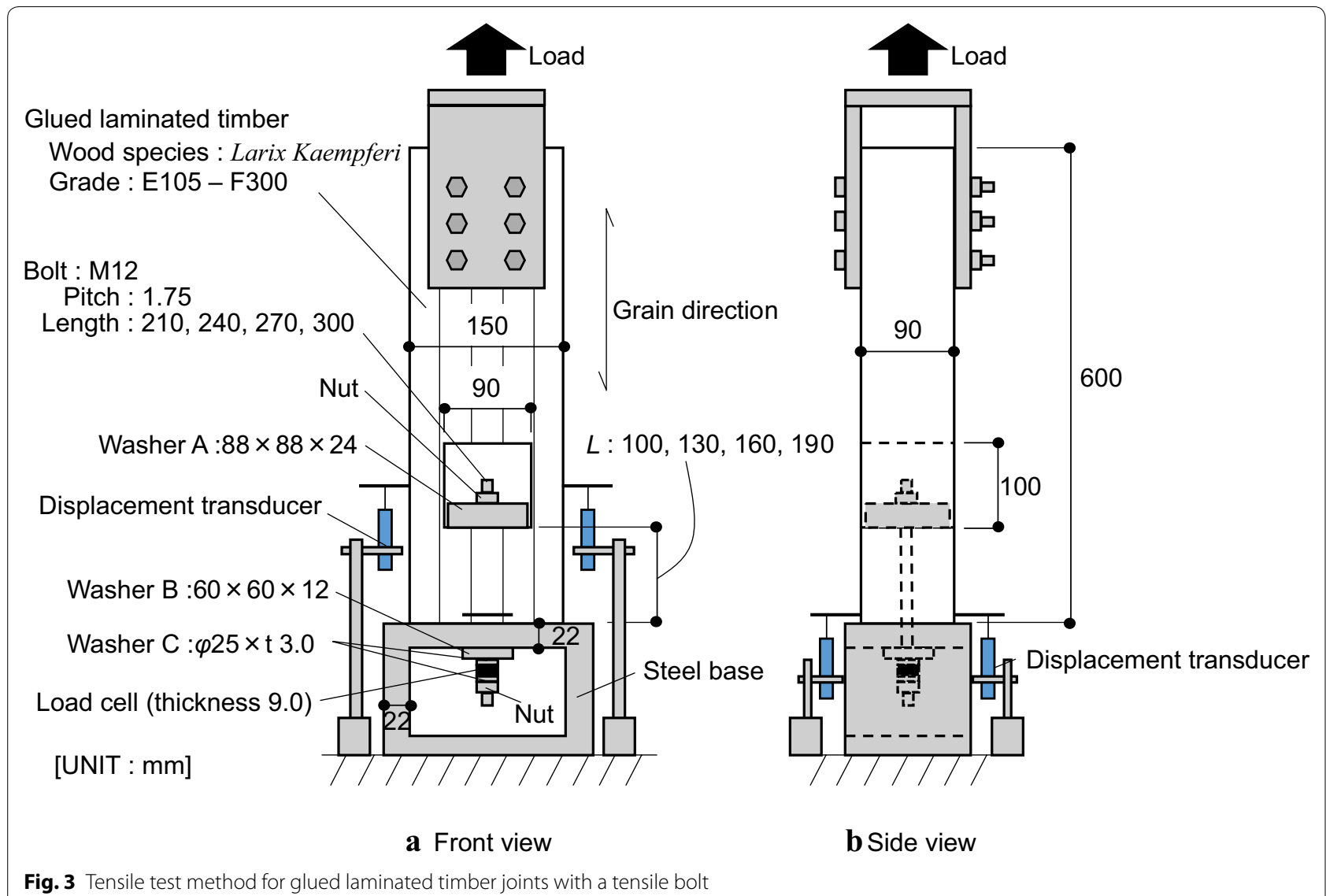

was $88 \times 88 \times 24 \mathrm{~mm}$ (bolt hole: $\Phi 14.5 \mathrm{~mm}$ ). Three and four different conditions were chosen, respectively, for initial tightening force $\left(F_{\mathrm{f}}\right)$ and distance from the washer to the member end $(L)$-a potential contributor to shear fracture-to determine their effects on load factor: $F_{\mathrm{f}}=13,21,30 \mathrm{kN}, L=100,130,160,190 \mathrm{~mm}$ (respective bolt lengths $=210,240,270,300 \mathrm{~mm})$. These $F_{\mathrm{f}}$ values correspond to 30,50 , and $70 \%$ of the bolt's $0.2 \%$ strength, determined by bolt tensile tests conducted in advance. The initial tightening force was applied by tightening the nut with a torque wrench, until the predetermined axial force appeared on a washer-type load cell installed in the steel base of the test apparatus (LCW-S-60KNSD22, Rated capacity: $60 \mathrm{kN}$, Kyowa electronic instruments corp.). Expecting some initial stress relaxation to $F_{\mathrm{f}}$, the bolt was tightened to $0.3-0.5 \mathrm{kN}$ higher than this value; testing started once the pre-set $F_{\mathrm{f}}$ was reached. Tests were done using a universal tester (AG-100kNX Plus, Shimadzu Corp.). A tensile load was applied parallel to the bolt axis, which was measured by a load cell attached to the crosshead, and increased monotonically until timber member or bolt destruction was observed. Crosshead speed was $5 \mathrm{~mm} / \mathrm{min}$. Displacement was measured by two pairs of transducers (DTH-A-30-K, Rated capacity:
$30 \mathrm{~mm}$, Kyowa electronic instruments corp.): one on either notched sides of the timber, and a front/rear pair between the 'legs' of the member end and the steel foundation (see configuration in Fig. 3). Three joints were tested in each condition ( $n=36$ total).

\section{Results and discussion}

Relationship between the axial bolt force and external load Figure 4 shows the representative curves of relationship between external load and displacement for all test conditions, as measured by the pair of transducers attached to the notched sides of the timber. Figure 5 shows the representative curves of relationship between axial bolt force and external load. First, in all series in Fig. 4, the profiles show a distinct pattern: a rapid and linear rise in external load early on, increasing proportional to the external load as the slope changes. Shear failure was observed under the $L=100 \mathrm{~mm}$ condition in the area from the lower washer (washer A: see Fig. 3) to where the legs meet the wood block (see Fig. 6a) in 6/9 specimens $(n=2$ at $F_{\mathrm{f}}=13 \mathrm{kN}, 3$ at $21 \mathrm{kN}$, and 1 at $30 \mathrm{kN}$ ). Shear failure occurred in the screw thread in the remaining three specimens in this condition, and in all specimens in the $L=160$ and $190 \mathrm{~mm}$ conditions (see Fig. 6c), and tensile 

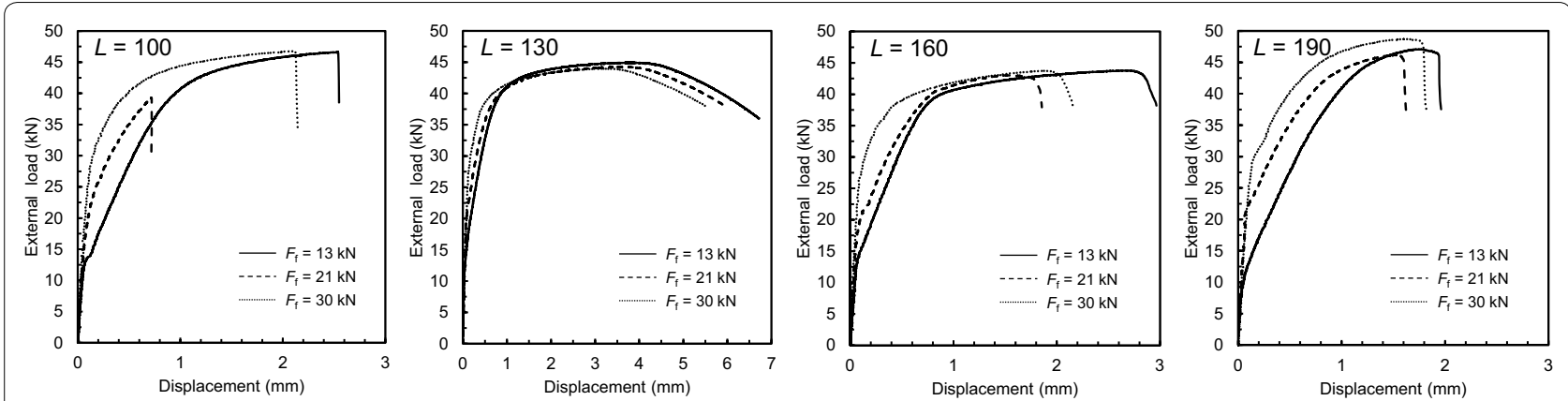

Fig. 4 Representative curves of relationship between external load and displacement of notch
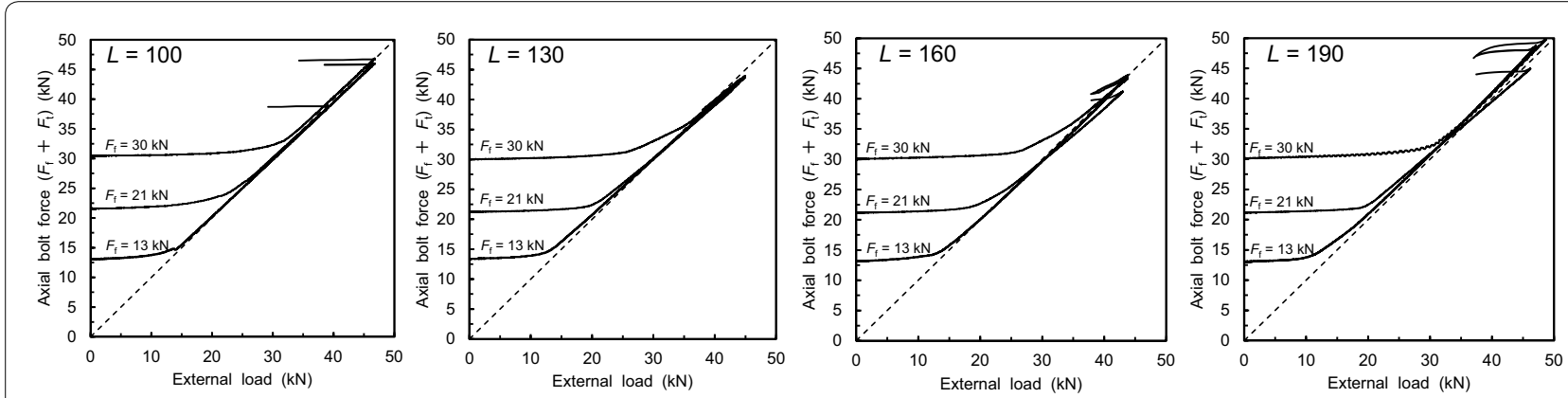

Fig. 5 Representative curves of relationship between axial bolt force and external load

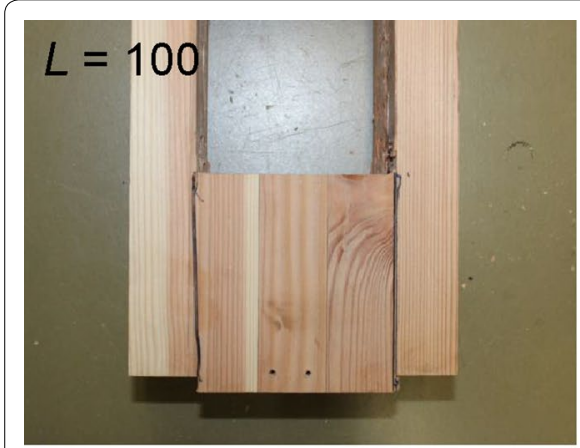

$\mathbf{a}$

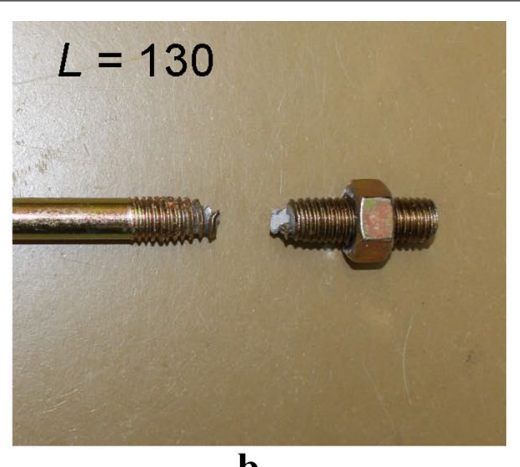

b

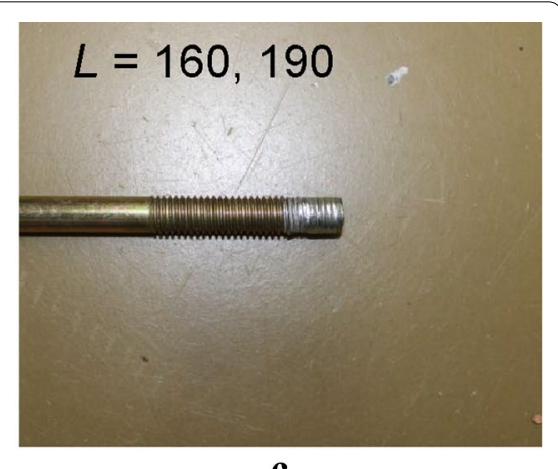

c

Fig. 6 Failure states of glued laminated timber members and tensile bolts after tensile test

failure of the bolt occurred in fully threaded portion in all specimens in the $L=130 \mathrm{~mm}$ condition (see Fig. 6b). Next, in all series in Fig. 5, after an initial linear segment, the axial bolt force approaches equivalence with the load at higher loads. In addition, $W_{\text {sep }}-$ i.e., the external load at which the initial linear segment intersects with the $45^{\circ}$ 'identity' line (axial bolt force $=$ external load) - becomes greater with increasing $F_{\mathrm{f}}$, irrespective of $L$. This trend is identical to that reported in [19]. Table 1 shows values for load factor $\phi$ calculated from the initial linear segment using the least-squares method. The table also shows stiffness $K$, calculated by the least-squares method for the initial linear slope in Fig. 4, as well as maximum tensile strength $P_{\max }$ and the displacement at maximum strength $\delta_{\max }$. The initial linear slope of $\phi$ and $K$ were decided as the interval from external load $1 \mathrm{kN}$ to $6.5 \mathrm{kN}$ (when $F_{\mathrm{f}}$ is $13 \mathrm{kN})$, from 1 to $10.5 \mathrm{kN}\left(F_{\mathrm{f}}=21 \mathrm{kN}\right)$, and from 1 to $15 \mathrm{kN}\left(F_{\mathrm{f}}=30 \mathrm{kN}\right) . \phi$ ranges from 0.02 to 0.04 , meaning that $2-4 \%$ of the external load is borne by the bolt axis. According to Eq. (1), the remaining more than $95 \%$ is 
Table 1 Results of load factor and mechanical properties of joints

\begin{tabular}{|c|c|c|c|c|c|c|}
\hline$L(\mathrm{~mm})$ & $F_{\mathrm{f}}(\mathrm{kN})$ & & $\varphi$ & $K(\mathrm{kN} / \mathrm{mm})$ & $P_{\max }(\mathrm{kN})$ & $\delta_{\max }(\mathrm{mm})$ \\
\hline \multirow[t]{6}{*}{100} & 13 & Ave. & 0.038 & 238 & 42.8 & 1.69 \\
\hline & & SD & 0.0060 & 20.7 & 5.36 & 0.89 \\
\hline & 21 & Ave. & 0.029 & 256 & 39.9 & 0.78 \\
\hline & & SD & 0.0100 & 17.8 & 0.77 & 0.05 \\
\hline & 30 & Ave. & 0.019 & 331 & 45.7 & 2.15 \\
\hline & & SD & 0.0009 & 21.5 & 0.96 & 1.03 \\
\hline \multirow[t]{6}{*}{130} & 13 & Ave. & 0.042 & 251 & 44.1 & 3.55 \\
\hline & & SD & 0.0016 & 16.9 & 0.68 & 0.38 \\
\hline & 21 & Ave. & 0.032 & 266 & 43.7 & 3.31 \\
\hline & & SD & 0.0181 & 63.6 & 0.44 & 0.26 \\
\hline & 30 & Ave. & 0.022 & 284 & 43.9 & 3.13 \\
\hline & & SD & 0.0022 & 26.6 & 0.0026 & 0.19 \\
\hline \multirow[t]{6}{*}{160} & 13 & Ave. & 0.041 & 225 & 43.9 & 2.59 \\
\hline & & SD & 0.0117 & 37.9 & 0.84 & 0.10 \\
\hline & 21 & Ave. & 0.037 & 267 & 44.3 & 2.34 \\
\hline & & SD & 0.0076 & 22.3 & 1.22 & 1.05 \\
\hline & 30 & Ave. & 0.032 & 275 & 44.1 & 2.24 \\
\hline & & SD & 0.0067 & 29.9 & 0.45 & 0.62 \\
\hline \multirow[t]{6}{*}{190} & 13 & Ave. & 0.039 & 241 & 47.4 & 1.94 \\
\hline & & SD & 0.0081 & 47.1 & 1.34 & 0.36 \\
\hline & 21 & Ave. & 0.033 & 246 & 47.1 & 1.62 \\
\hline & & SD & 0.0071 & 28.1 & 0.83 & 0.10 \\
\hline & 30 & Ave. & 0.035 & 234 & 47.6 & 1.89 \\
\hline & & $\mathrm{SD}$ & 0.0051 & 41.0 & 2.29 & 1.02 \\
\hline
\end{tabular}

$L$ : side length, $F_{\mathrm{f}}$ : tightening force, $\varphi$ : load factor, $K$ : elastic stiffness, $P_{\max }:$ maximum tensile strength, $\delta_{\text {max }}$ : maximum displacement in maximum tensile strength, Ave.: average, SD: standard deviation

acting to separate the joint interface. In addition, average values of $\phi$ decreases with increasing $F_{\mathrm{f}}$ in the $L=100$, 130 , and $160 \mathrm{~mm}$ conditions, but this relation grows weaker at higher $L$. $K$ also increases with increasing $F_{\mathrm{f}}$ under the $L=100,130$, and $160 \mathrm{~mm}$ conditions. Figure 7 shows the relationship between $K$ and $\phi$. This correlation is relatively distinct, showing decreasing $K$ with increasing $\phi$. This tendency is presumed to be due to the tensile elongation of the bolt. Under the $L=190 \mathrm{~mm}$ condition, however, $F_{\mathrm{f}}$ has no apparent associations with either $\phi$ or $K$.

Yoshimoto et al. found $\phi$ to be near constant and independent of $F_{\mathrm{f}}$ [19], contrasting with the trends observed here under most of the test conditions $(L=100,130$, $160 \mathrm{~mm}$ ). Sawa [20] demonstrated, both theoretically and empirically, that in bolted-joint assemblies of metallic material, $\phi$ varies depending on the spring constant of the bolt and that of the material being fastened, and that it greatly varies depending on the position of the external load is applied. In this experiment, the position of external load application is same in all series. However, stress distribution may change to $F_{\mathrm{f}}$ in region from the washer

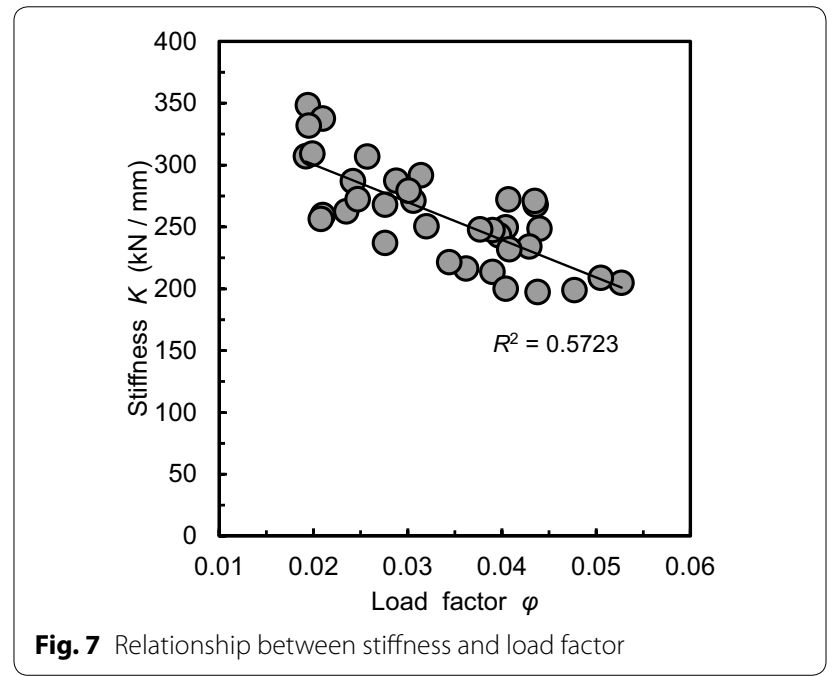

to the member end $(L)$. Therefore, we can deduce that the spring constant and load factor varied in response to changes in stress distribution to $F_{\mathrm{f}}$ in the $L=100,130$, 

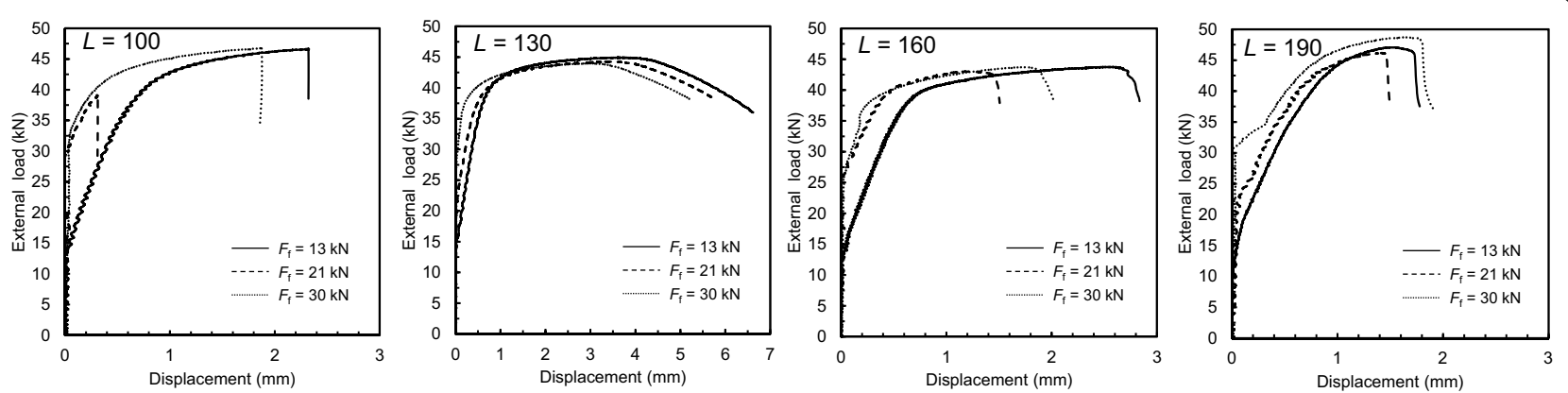

Fig. 8 Representative curves of relationship between external load and displacement of joint interface

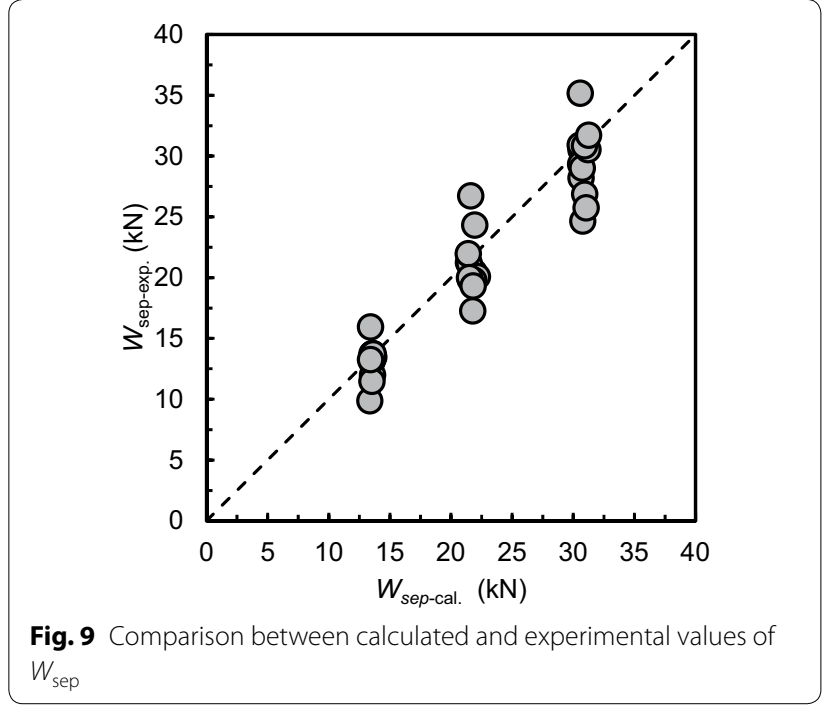

and $160 \mathrm{~mm}$ conditions; since stress distribution did not change with $F_{\mathrm{f}}$ in the $L=190 \mathrm{~mm}$ condition, the load factor did not change appreciably.

\section{Interface separation load}

Figure 8 shows the representative curves of relationship between external load and the displacement between the glulam leg and steel foundation for all test conditions. These profiles are similar to in Fig. 4: the external load increases as the initial slope changes, in a manner proportional to $F_{\mathrm{f}}$. Initially, the joint is stiff, with almost no displacement. These figures can be used to determine $W_{\text {sep-exp. }}$-the observed load required to completely separate the joint interface-and compare it with corresponding theoretical values derived from Eq. (4) above $\left(W_{\text {sep-cal. }}\right) . W_{\text {sep-exp. }}$ was defined as the external load of just before the gradient changes in initial behavior. Figure 9 shows the results. Overall, $W_{\text {sep-cal. }}$ tended to be greater than $W_{\text {sep-exp. }}$ It is considered that most of $W_{\text {sep- }}$ exp. was evaluated as start of separation load. This can be seen from, for example, $L=100 \mathrm{~mm} \times F_{\mathrm{f}}=21 \mathrm{kN}$ condition in Fig. 5, the curve starts to become non-linear at the external load lower than $W_{\text {sep-cal. }}$ On the other hand, four specimens with $W_{\text {sep-exp. }}$ clearly larger than $W_{\text {sep-cal. }}$ For example, when focusing on $L=130 \mathrm{~mm} \times F_{\mathrm{f}}=30 \mathrm{kN}$ condition in Fig. 5, the bolt axial force indicates a linear inclination of $45^{\circ}$ with the external load larger than $W_{\text {sep-cal }}$. It is considered that the joint interface was not completely separated until the external load larger than $W_{\text {sep-cal. }}$

From these results, the joint interface begins to separate at the lower external load than $W_{\text {sep-cal. }}$ On the other hand, there is also the behavior of completely separating under the external load greater than $W_{\text {sep-cal. }}$ Therefore, its care must be taken when evaluating the joint interface separation behavior.

\section{Conclusions}

In this study, we empirically investigated the effects of the initial tightening force of a bolted, glued laminated timber joint on its load factor and interface separation load when placed under a tensile load. The following major findings can be concluded from the data:

1. Load factor decreases with increasing initial tightening force; however, this tendency is reduced, the greater the washer-member-end distance.

2. Stiffness decreases with increasing load factor.

3. Interface separation load increases with increasing initial tightening force.

4. The joint interface begins to separate at the lower external load than theoretical values for interface separation load calculated based on load factor and initial tightening force.

\section{Acknowledgements}

We would like to thank Uni-edit (https://uni-edit.net/) for proofreading this manuscript.

Part of this article was presented at the 69th Annual Meeting of the Japan Wood Research Society, Hakodate, Japan, March 2019. 


\section{Authors' contributions}

DM designed and performed the experiments and analyzed the data. YW, $\mathrm{HS}$, and AK assisted in the preparation of the tests. DM wrote the manuscript in consultation with YW, HS, and AK. All authors read and approved the final manuscript.

\section{Funding}

This work was supported in part by Grants from the Japan Society for the Promotion of Science (KAKENHI, JP19K06180).

\section{Availability of data and materials}

Not applicable.

\section{Ethics approval and consent to participate}

Not applicable.

\section{Consent for publication}

We agree to allow our manuscript being published.

\section{Competing interests}

The authors declare that they have no competing interests.

\section{Author details}

${ }^{1}$ Tokyo Metropolitan Industrial Technology Research Institute, 2-4-10, Aomi, Koto-Ku, Tokyo 135-0064, Japan. ${ }^{2}$ Toyama Prefectural Agricultural, Forestry \& Fisheries Research Center, 4940, Imizu, Toyama 939-0311, Japan. ${ }^{3}$ Sugiyama Jogakuen University, 17-3, Chikusa-ku, Nagoya, Aichi 464-8662, Japan.

${ }^{4}$ Research Institute for Sustainable Humanosphere, Kyoto University, Uji, Kyoto 611-0011, Japan.

Received: 8 October 2019 Accepted: 7 February 2020

Published online: 17 February 2020

\section{References}

1. Sawata K (2015) Strength of bolted timber joints subjected to lateral force. J Wood Sci 61:221-229

2. Hirai T (2007) Current issues of timber construction. Mokuzai Gakkaishi 53:117-126 (in Japanese)

3. Hirai T (1991) Effect of frictional resistance on lateral resistance of bolted timber-joints with steel side-webs. Mokuzai Gakkaishi 37:517-522 (in Japanese)

4. Awaludin A, Hirai T, Hayashikawa T, Sasaki Y (2008) Load-carrying capacity of steel-to-timber joints with a pretensioned bolt. J Wood Sci 54:362-368

5. Matsubara D, Shimada M, Hattori N (2013) Effect of tightening axial force on shear strength of the lumber-to-lumber bolted joints. Mokuzai Kogyo 68:382-386 (in Japanese)

6. Awaludin A, Hirai T, Toshiro T, Sasaki Y, Oikawa A (2008) Effects of pretension in bolts on hysteretic responses of moment carrying timber joints. J Wood Sci 54:114-120

7. Hirai T, Meng Q, Sawata K, Koizumi A, Sasaki Y, Uematsu T (2008) Some aspects of frictional resistance in timber constructions. In: Proceedings of the world conference on timber engineering 2008, Miyazaki, 2-5 June 2008

8. Meng Q, Hirai T, Sawata K, Sasaki Y, Koizumi A, Uematsu T (2010) Effect of frictional force on lateral resistance of wall-floor joints of wooden light frame constructions. Mokuzai Gakkaishi 56:48-54 (in Japanese)

9. Wakashima Y, Shimizu H, Ishikawa K, Fujisawa Y (2015) Development of high damping shear walls using wood friction. In: Abstracts of the international symposium on wood science and technology 2015 (IAWPS 2015), Tokyo, 15-17 March 2015

10. Wakashima Y, Shimizu H, Fujisawa Y, Ishikawa K, Kitamori A, Matsubara D (2016) High damping shear walls using wood friction joints. In: Proceeding of world conference on timber engineering 2016, Vienna University of Technology, Vienna, 22-25 August 2016

11. Wakashima Y, Shimizu H, Ishikawa K, Fujisawa Y, Tesfamariam S (2019) Friction-based connectors for timber shear walls: static experimental tests. J Archit Eng 25:04019006-1-04019006-9

12. Matsubara D, Wakashima Y, Fujisawa Y, Shimizu H, Kitamori A, Ishikawa K (2017) Tightening torque calculation method for plastic clamp force of bolted timber joints. Mokuzai Gakkaishi 63:162-175 (in Japanese)
13. Matsubara D, Wakashima Y, Fujisawa Y, Shimizu H, Kitamori A, Ishikawa K (2017) Relationship between clamp force and pull-out strength in lag screw timber joints. J Wood Sci 63:625-634

14. Matsubara D, Wakashima Y, Fujisawa Y, Shimizu H, Kitamori A, Ishikawa K (2018) Effects of tightening speed on torque coefficient in lag screw timber joints with steel side plates. JWood Sci 64:112-118

15. Matsubara D, Wakashima Y, Fujisawa Y, Shimizu H, Kitamori A, Ishikawa K (2019) A novel method for estimating ultimate clamp force in lag screw timber joints with steel side plates. Trans Mater Res Soc J.pn 44:109-113

16. Matsubara D, Wakashima Y, Kitamori A, Shimizu H, Ishikawa K, Fujisawa Y (2018) Pull-out stress relaxation behavior of lag screw timber joints under indoor environment. In: Green S (ed) Proceedings of the 2018 society of wood science and technology/japan wood research society international convention, Nagoya, 2018

17. Wakashima Y, Fujisawa Y, Shimizu H, Kitamori A, Matsubara D, Ishikawa K (2019) Relaxation behavior of wood combined with accelerated treatment and retightening. In: Abstracts of the 69th annual meeting of the japan wood research society in Hakodate, Hakodate Arena, Hakodate, March 2019

18. Wakashima Y, Shimizu H, Kitamori A, Matsubara D, Ishikawa K, Fujisawa Y (2019) Stress relaxation behavior of wood in the plastic region under indoor conditions. J Wood Sci 65:1-9

19. Yoshimoto I, Maruyama K, Sawa T, Nishiguchi N (1976) The force ratio of bolted joints: the case where clamped parts are hollow cylinders. Trans Japan Soc Mech Eng 42:2174-2184 (in Japanese)

20. Sawa T (1977) On the influence of the position of the load application on the force ratio of bolted joints. Reports of the Faculty of Engineering, Yamanashi University 28, pp 1-9 (in Japanese)

21. Hagiwara M (1982) Simplified calculation method for force ratio of bolted joints: case of cylindrical clamped parts subjected to axially symmetrical tensile load. Trans Jpn Soc Mech Eng Ser C 48:622-625 (in Japanese)

22. Tanaka M, Yamada A (1985) The behaviour of fasteners under service leading: force ratio of threaded connection. Trans Japan Soc Mech Eng Ser C 51:1362-1371 (in Japanese)

23. Sawa T, Kumano H, Morohoshi T (1996) The contact stress in a bolted joint with a threaded bolt. Exp Mech 36:17-23

24. Zhang O (2005) Discussions on behavior of bolted joints in tension. J Mech Des 127:506-510

25. Williams JG, Anley RE, Nash DH, Gray TGF (2009) Analysis of externally loaded bolted joints: analytical, computational and experimental study. Int J Press Vessels Piping 86:420-427

26. Nasser SA, Yang X, Gandham SVT, Wu Z (2011) Nonlinear deformation behavior of clamped bolted joints under a separating service load. J Press Vessel Technol 133:02100-1-02100-9

27. Suzuki K, Goto T, Fujita K, Tsuchimoto T, Aoki K, Soma T, Inayama M (2015) Influence of MOE and density on tensile strength properties of tensile bolt joint with CLT. Wood Ind 70:158-163 (in Japanese)

28. Suzuki K, Kobayashi K, Aoki K, Inayama M, Tsuchimoto T (2016) Estimation of strength properties of tensile bolt joint for CLT construction. J Struct Constr Eng 81:1289-1298 (in Japanese)

29. Hayasaki Y, Araki Y, Kawai N, Inayama M, Nakajima S (2017) An experimental study on shear length and fracture features of tensile bolt of glued laminated timber frame joints. J Struct Constr Eng 82:1055-1062 (in Japanese)

30. Araki Y, Inayama M, Isoda H, Koshihara M, Miyata Y, Nakajima S, Yamaguchi Y (2018) Study on joint ductility assurance design of glued laminated timber frame with tensile bolts type joint. J Jpn Assoc Earthq Eng 18:63-74

31. Zhang Y, Kobayashi K, Yasumura M, Davenne L (2018) Mechanical properties of joints with tensile bolts on cross-laminated timber structures. Wood Ind 73:180-186 (in Japanese)

32. Zhang Y, Kobayashi K, Yasumura M (2019) Seismic behavior of CLT shear walls connected with tensile bolted joints and screwed steel joints. Mokuzai Gakkaishi 65:71-82 (in Japanese)

\section{Publisher's Note}

Springer Nature remains neutral with regard to jurisdictional claims in published maps and institutional affiliations. 